
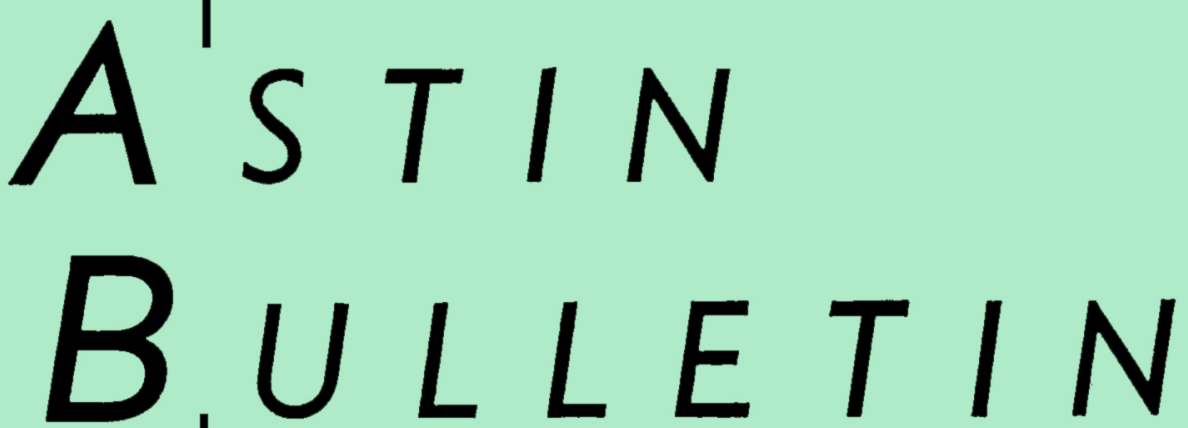

A Journal of the International Actuarial Association

EDITORS :

Hans Bühlmann Switzerland

D. Harry Reid United Kingdom

Co-Editors :

Alois Gisler Switzerland

David Wilkie United Kingdom

Edtorial Board:

Björn Ajne Sweden

Marc Goovaerts Belgium

Jacques Janssen Belgium

William S. Jewell USA

Jean Lemaire Belgium/USA

Walther Neuhaus Norway

\section{Jukka Rantala} Finland

Axel Reich Germany

James A. Tilley
Contents

\section{EDITORIAL AND ANNOUNCEMENTS}

Guest Editorial

Obituary on Sidney Benjamin

\section{ARTICLES}

J.-L. Besson, Ch. Partrat

Trend et systèmes de Bonus-Malus

H. R. KÜNSCH

Robust Methods for Credibility

C. M. Ramsay

Improving Goovaerts' and De Vylder's

Stable Recursive Algorithm

B. SUNDT

On some Extensions of Panjer's Class of Counting Distributions

\section{WORKSHOP}

Ph. Artzner, F. Delbaen

Credit Risk and Prepayment Option

L. TREMBLAY

Using the Poisson Inverse Gaussian in

Bonus-Malus Systems

M.-H. AMSLER

Risque de décès et risque de ruine: Réflexions

sur la mesure du risque de ruine

Letter to the Editors

Book Review

Actuarial Vacancies 


\section{EDITORIAL POLICY}

ASTIN BULLETIN started in 1958 as a journal providing an outlet for actuarial studies in non-life insurance. Since then a well-established non-life methodology has resulted, which is also applicable to other fields of insurance. For that reason ASTIN BULLETIN will publish papers written from any quantitative point of view-whether actuarial, econometric, engineering, mathematical, statistical, etc. - attacking theoretical and applied problems in any field faced with elements of insurance and risk.

ASTIN BULLETIN appears twice a year (May and November), each issue consisting of at least 80 pages.

Details concerning submission of manuscripts are given on the inside back cover.

\section{MEMBERSHIP}

ASTIN and AFIR are sections of the International Actuarial Association (IAA). Membership is open automatically to all IAA members and under certain conditions to non-members also. Applications for membership can be made through the National Correspondent or, in the case of countries not represented by a national correspondent, through a member of the Committee of ASTIN.

Members of ASTIN receive ASTIN BULLETIN free of charge. As a service of ASTIN to the newly founded section AFIR of IAA, members of AFIR also receive ASTIN BULLETIN free of charge.

\section{SUBSCRIPTION AND BACK ISSUES}

ASTIN BULLETIN is published and printed for ASTIN by Ceuterick s.a., Brusselsestraat 153, B-3000 Leuven, Belgium.

All queries and communications concerning subscriptions, including claims and address changes, and concerning back issues should be sent to Ceuterick.

The current subscription or back issue price per volume of 2 issues including postage is BEF 1700 .

Back issues up to issue 10 (= up to publication year 1979) are available for half of the current subscription price.

\section{INDEX TO VOLUMES 1-20}

The Cumulative Index to Volumes 1-20 is also published for ASTIN by Ceuterick at the above address and is available for the price of BEF 400 . 


\section{EDITORIAL AND ANNOUNCEMENTS}

\section{THANK YOU LEROY SIMON!}

By the end of 1991 we learned that LeRoy Simon has resigned from the ASTIN Committee, on which he has duly served as representative of IAA. LeRoy has had an ever lasting influence on the development of ASTIN. In particular, he has been very successful in anchoring ASTIN to fertile interaction with the Casualty Actuarial community in the United States.

LeRoy Simon joined the ASTIN Committee in 1974. He was chairman of ASTIN in the years 1977 and 1978. For 7 years he was member of the Editorial Board of ASTIN Bulletin. In view of his great merits we have invited LeRoy to write a guest editorial for this issue. We are happy that LeRoy has accepted the challenge with enthusiasm.

We use the opportunity to thank LeRoy heartily for his great and successful engagement for ASTIN.

The Editors 